\title{
Effects of Boiling and Smoking on the Proximate Composition and Oil Quality of a Commercially Important Freshwater Fish (Chrysichthys nigrodigitatus) from Nkam River in Cameroon
}

\begin{abstract}
Djopnang Djimbie Justin ${ }^{1}$, Tchoumbougnang François ${ }^{1,4}$, Tomedi-Tabi Eyango Minette ${ }^{1}$, Womeni Hilaire Macaire $^{2}$, Tonfack Djikeng Fabrice ${ }^{2}$, Prabhakar Iruku Naga Satya ${ }^{3}$, Karuna Mallampalli Sri Lakshmi ${ }^{3}$, Karuna Mallampalli Sri Lakshmi ${ }^{3}$, Prasad Rachapudi Badari Narayana ${ }^{3}$, Kemmo Signing Steve ${ }^{1}$ \& Gouado Inocent ${ }^{4}$

${ }^{1}$ Laboratory of Fisheries and Aquatic resources - Institute of Fisheries and Aquatic Sciences at Yabassi, University of Douala, Po Box 7236 Douala, Cameroon

${ }^{2}$ Department of Biochemistry, Faculty of Science, University of Dschang, PO Box 67 Dschang, Cameroon

${ }^{3}$ CSIR-Indian Institute of Chemical Technology, Center for Lipid Research, Tarnaka, Hyderabad 500007, India

${ }^{4}$ Laboratory of Biochemistry, Faculty of Science, University of Douala, 24157 Douala, Cameroon

Correspondence: Gouado Inocent, Laboratory of Biochemistry, Faculty of Science, University of Douala, 24157

Douala, Cameroon. E-mail: gouadoi@yahoo.fr
\end{abstract}

Received: March 9, 2018 Accepted: March 23, $2018 \quad$ Online Published: October 9, 2018

doi:10.5539/jfr.v7n6p59 URL: https://doi.org/10.5539/jfr.v7n6p59

\begin{abstract}
The effects of boiling and smoking on the proximate composition and lipids quality of a freshwater fish (Chrysichthys nigrodigitatus) collected from Nkam River in Cameroon were investigated. Fresh fish was filled, boiled or smoked and then, aliquoted for analyses. One portion was dried at $50{ }^{\circ} \mathrm{C}$ and ground into flour for the proximate composition determination. The other portion was served for lipids extraction using the Bligh and Dyer method. The extracted oil was characterized physico-chemically using chemical indexes and GC/FID. Moisture, protein, ash and lipid contents of raw fish were 80.67 $\pm 4.18,64.42 \pm 1.51,10.90 \pm 0.42$ and $22.06 \pm 5.40 \%$ $\mathrm{dm}$ respectively. The changes in dry matter, protein and ash contents were found to be statistically significant $(\mathrm{P}<0.05)$ after smoking. The most important mineral of this fish was the Potassium $(7017.54-8771.93 \mathrm{mg} / \mathrm{kg})$. Except the calcium and phosphorus contents which decreased with the treatments, the amount of the other detected minerals was significantly increased. It was also found that these technological treatments significantly increased $(\mathrm{P}<0.05)$ the free fatty acids and hydroperoxides formation in oil, while it decreased its iodine value. The fatty acid profile of untreated and treated fish revealed her richness in Palmitic (22.91-34.76\%), Oleic (12.83-23.55\%), Stearic (11.29-14.81\%), Linoleic (LA) ( $\omega 6)$ (2.83-6.75\%), Arachidonic $(\omega 6)(2.50-6.64 \%)$ and Docosahexaenoic (DHA) ( 13$)(1.56-12.31 \%)$ acids. The ratio PUFA/SFA of raw fish (0.47) was severely reduced by the smoking (0.26) while it increases after boiling (0.61). This fish contain appreciable levels of Omega-6 PUFA, suggesting that it could be used as a source of healthy diet for human beings. These findings may also be beneficial for the fish industry, nutritionists and researchers who were striving to improve the nutritive value, processing and marketing of selected fish species.
\end{abstract}

Keywords: Chrysichthys nigrodigitatus, chemical composition, fatty acids, fresh fish, smoking, boiling, Nkam river

\section{Introduction}

Fishes are very important animal proteins source which can be exploited for preventing food insecurity in both rural and urban areas of Cameroon. They serve as feeds for livestock, poultry and carnivorous fish. Apart from being the richest source of high quality protein, vitamins and essential minerals, they are virtually a unique and good source of $n-3$ and n- 6 long-chain poly-unsaturated fatty acids (PUFAs). The nutritional importance of seafood, fats and oils has increased substantially because of their health benefit effects (Azamand \& Ali, 2004). Fish containing high n-3/n-6 PUFAs ratios is important for human health and it has been proven that regular fish consumption reduces the risk of cardiovascular diseases, enhances neurodevelopment of infants, leads to improvement in learning ability and prevents cancers (Suzuki et al., 1998; Mozaffarian et al., 2005). PUFAs are also essential in maintaining the functions of living cell membranes. Moreover, they are useful in making 
prostaglandins which regulate many body processes, notably the inflammation and blood clotting. Fish fats are equally needed to absorb fat soluble vitamins A, D, E and K from food and for regulating body cholesterol metabolism (Connor, 2000; Kris-Etherton et al., 2003). Clinical results of an epidemiological research suggest that, eicosapentaenoic (EPA) and docosahexaenoic (DHA) acids, found only in fish and seafood, possess extremely beneficial properties for human coronary artery disease prevention. Additionally, fish oil helps in preventing brain aging and Alzheimer's disease (Conner, 1997). Many health experts recommend the consumption of seafood 2 or 3 times a week. This is mostly recommended for pregnant women, children and elderly people (Krauss et al., 2000). Consumption of EPA and DHA may reduce the risk of mortality due to cardiovascular diseases (Conner, 1997; Krauss et al., 2000). Although the hydrographic network of Cameroon is wide with an abundant and diversified aquatic fauna (Vivien, 1991), very few studies on their nutritional quality have been addressed in the literature. Chrysichthys nigrodigitatus is a species of fish in the family of claroteidae (Hopkins et al., 2007). This freshwater fish is of great commercial value at Yabassi and is interesting for consumption after boiling or smoking. However, very few studies have been done in Cameroon from this species. Previous works on this species include Tenyang et al. (2016) and Mouokeu et al. (2018). The first studied the proximal, mineral and fatty acid composition of raw C. nigrodigitatus, from the Maga Lake in Far North region. The second analyzed the chemical composition and antibacterial activity of oil of $C$. nigrodigitatus from Nkam River at Yabassi, extracted hot by pressing and maceration in hexane. Furthermore, no study made mention of the effects of boiling and smoking generally applied on their nutritional potential and the quality of their lipids. These effects are not yet been reported and remain unknown in this species of fish. Studies of nutrient intake from fish in relation to health are frequently carried out with data obtained from raw food. But, chemical contents in raw fish tissue might not provide explicit information on the nutritive value of the species after technological treatments. The objective of this study is to assess the influences of smoking and boiling on the proximate composition and fat quality of $C$. nigrodigitatus from Nkam River at Yabassi.

\section{Material and Methods}

\subsection{Sample Preparation and Cooking}

Fish samples (Chryschsthys nigrodigitatus) were obtained from the landing stages of the Nkam River at Yabassi-Cameroon, located at Titina: $4^{\circ} 45^{\prime}$ North latitude and 9 ${ }^{\circ}$ 97' East Longitude, former River Port $4^{\circ} 27^{\prime}$ North Latitude and $9^{\circ} 57^{\prime}$ East Longitude and Bodiman $4^{\circ} 24^{\prime}$ North latitude and $9^{\circ} 53^{\prime}$ East longitude. The fishes were harvested, transferred into ice containing boxes and transported to the laboratory. Identification was made by ichthyologists of the Laboratory of Ecosystem and Fisheries Resources of the Institute of Fisheries and Aquatic Sciences.

\subsection{Boiling Procedures}

Fresh fishes were washed with tap water to remove adhering blood and slime. They were prepared using a handling process, i.e. eviscerating, beheading, washing, and then cooked by boiling. The fishes were dipped into boiling water at the ratio of $1: 1.5(\mathrm{w} / \mathrm{v})$ for 20 minutes at $98^{\circ} \mathrm{C}$ (water temperature).

\subsection{Smoking Procedures}

The traditional heat smoking methods was used in the "banda chorhor" room for smoking. Firewood was set up in the combustion chamber and then lighted. The smoking temperature was monitored in the smoking chamber using a thermometer. Fish samples were then placed on the mesh in the kiln after weighing. The burning wood was adjusted continuously to maintain the required temperature in the chamber during the three smoking periods. During the pre-drying phase, the temperature was kept low between 32 and $50{ }^{\circ} \mathrm{C}$ for $2 \mathrm{~h}$. During cooking-smoking, the temperature was between 60 and $80{ }^{\circ} \mathrm{C}$ for $2 \mathrm{~h} 30$ minutes and in the final phase smoking-drying, the temperature was decreased and maintained between 50 and $60^{\circ} \mathrm{C}$ for $2 \mathrm{~h} 30$ minutes.

\subsection{Sample Collection}

After boiling or smoking, the bones of fishes were removed; meanwhile the fresh samples were filled in parallel. These samples of raw, boiled and smoked fish were then aliquoted for analysis. After evaluating their moisture content, a portion of the aliquots was dried at $50{ }^{\circ} \mathrm{C}$ and ground into flour in which proximal and mineral composition has been determined. For lipids analysis, the extraction was done in the other portion using a mixture of solvent chloroform, methanol, according to the Bligh and Dyer (1959) method.

\subsection{Proximate Composition Analysis}

The moisture content of $C$. nigrodigitatus was determined by drying the meat in an electric air dried oven at $105^{\circ} \mathrm{C}$, until a constant weight was obtained as described by AOAC method (AOAC, 1990). Crude protein (CP) content was calculated by converting the nitrogen content determined via Kjeldahl's method $(6.25 \mathrm{xN})$. Fat $(\mathrm{F})$ 
was determined by the method described by the AOAC (1990) using the Soxhlet system apparatus, with a non-polar solvent hexane. Ash (A) content was evaluated by dry-aching in a furnace at $550^{\circ} \mathrm{C}$ for $24 \mathrm{~h}(\mathrm{AOAC}$, 1990). Total carbohydrates (C) were determined by subtracting the sum of \% F, \% CP and \% A contents from $100 \mathrm{~g}$ of fish dry matter (Onyeike et al., 2000). Gross energy value of each sample was calculated, by multiplying the percentage CP, F and total Carbohydrate (C) contents with their respective energy values of 4, 9 and $4 \mathrm{kcal}$ per $100 \mathrm{~g}$ of fish dry matter $(\mathrm{dm})$.

\subsubsection{Mineral Analysis}

For mineral determination, the samples were digested in $\mathrm{HNO}_{3} / \mathrm{HClO}_{4}$ (Pauwels et al., 1992). The elements Fe, $\mathrm{Zn}$ and $\mathrm{P}$ were determined using a spectrophotometer. While Sodium (Na) and potassium (K) were measured by flame photometry, calcium $(\mathrm{Ca})$ and magnesium $(\mathrm{Mg})$ were measured by titration, using EDTA-complex metric method (AOAC, 2000).

\subsubsection{Chemical Analysis for Lipids Quality}

The extracted oils of samples were characterized through the assessment of their Iodine $\left(\mathrm{I}_{2}\right)$, Peroxide $(\mathrm{PV})$ and free fatty acid (FFA) values as per the AFNOR official methods (AFNOR, 1981).

\subsubsection{Fatty Acids Profile of Fish Oil Analysis}

Fatty acids profiles of oils samples were investigated following the conversion of their fatty acids into fatty acids methyl esters (FAMEs). Then they were prepared by trans-esterification using $2 \%$ of sulfuric acid in methanol (Christie, 1993). The FAMEs were extracted into ethyl acetate and thoroughly washed with water to make them free of acid and dried over anhydrous sodium sulfate. The dried esters were analyzed in Gas chromatography flame ionize detector (GC-FID). The GC-FID analyses were performed with an Agilent (Agilent Technologies, Palo Alto, CA, USA) 7890A series gas chromatograph equipped with a FID detector using a DB-225 capillary column $\left(30 \mathrm{~m} \times 0.25 \mathrm{~mm}, 0.25 \mu \mathrm{m}\right.$ of film thickness). The column temperature initially maintained at $160^{\circ} \mathrm{C}$ for 2 minutes, was subsequently increased to $220^{\circ} \mathrm{C}$ at $5^{\circ} \mathrm{C}$ /minutes and maintained for $10 \mathrm{~min}$ at $220^{\circ} \mathrm{C}$. The carrier gas utilized was nitrogen at a flow rate of $1.5 \mathrm{ml} / \mathrm{min}$. The injector and detector temperatures were maintained at 230 and $250^{\circ} \mathrm{C}$, respectively with a split ratio of $50: 1$. The identification of fatty acid was based on the comparison of retention time with that of standard reference fatty acid methyl esters performed under same conditions.

\subsubsection{Statistical Analysis}

Completely Randomized Design (CRD) was adopted in carrying out the experiment. Experimental trials on evaluation of the physicochemical properties of each sample were conducted at least three times. One-way analysis of variance (ANOVA) with a level of significance $\mathrm{P}<0.05$ was applied to the different sample values obtained. The differences among the means were characterized by the multiple comparison test of Tukey Kramer. Graph Pad InStat Software Inc (C) 1992-2000 version 3.05, 32 bit for Win 95/NT was used for the data analysis.

\section{Results and Discussions}

\subsection{Proximate composition}

Results of the proximate analysis carried out on fresh, smoked and boiled C. nigrodigitatus are presented in Table 1. The average values obtained on the raw flesh of this fish were $80.67 \% \mathrm{fw}$ for the water content, $64.42 \% \mathrm{dm}$ for the crude protein, $22.06 \% \mathrm{dm}$ for the crude lipid, $10.90 \% \mathrm{dm}$ for the crude ash and $2.62 \% \mathrm{dm}$ for the crude carbohydrates. These values differ from the $78.46 \% \mathrm{fw}, 39.73,30.34,7.32$ and $22.61 \% \mathrm{dm}$ found by Tenyang et al. (2016) respectively on the same fish species in the Maga Lake in Far North. However, this proximate composition was not far from the one found by Tenyang et al., (2013). These authors found $76.48 \%$ fw, 64.24, 23.02, 10.98 and $1.76 \%$ fw respectively on a catfish Arius maculatus from Wouri. It is clear that the flesh of $C$. nigrodigitatus is dominated by water. This result is in agreement with Tenyang et al. (2014) and (2016) on the catfish. Also, value of water content of this fish is in the range of 70-85 g / $100 \mathrm{~g} \mathrm{FW}$ described by Yeannes and Almandos (2003) on the fresh fish. The fat content of our fresh samples is lower than that found by Tenyang et al. (2016) on the same species in the Far North-Cameroon. This fat value is similar to that of $A$. maculatus from Wouri (Tenyang et al., 2014) and fall within the range of $17.16-39.06 \% \mathrm{dm}$ found by Olele (2012) on C. nigrodigitatus from Niger River between September and February. Protein of raw C. nigrodigitatus of this study is similar to that of A. maculatus from Wouri (Tenyang et al., 2014), but remains very high than the same species collected in the Maga Lake in the far North (Tenyang et al., 2016). This value is also very high compared to the range $0.86-14.15 \%$ found by Olele (2012) on C. nigrodigitatus of Niger. The carbohydrate content of our raw sample is very small compared to that found $(22.61 \% \mathrm{DW})$ by Tenyang et al. (2016) and the range $(4.23-14.11 \%)$ recorded by Olele (2012). The high protein levels recorded is proving that this fish could 
be used to enrich the basic food rations and prevent its deficiency-related diseases. To be healthy, the FAO (Food and Agricultural Organization) and WHO (World Health Organization) (2007) recommend a protein intake of $0.66 \mathrm{~g} / \mathrm{kg}$ of weight body/day. Overall the differences observed in the nutritional composition of $C$. nigrodigitatus could be explained by some variation of the extrinsic factors (geographic areas, quality of water (temperature, salinity and turbidity), quality and availability of food, migration) and intrinsic factors (species, breeding period, age, sex and size at capture) (Ackman, 1990; Argen et al., 1991; Rao et al., 1995 and Sargent et al., 2002).

Table 1. Proximate composition of raw, smoked and cooked C. nigrodigitatus

\begin{tabular}{|c|c|c|c|}
\hline Parameters & Raw & Smoked & Boiled \\
\hline Moisture (\%) & $80.67 \pm 4.18_{\mathrm{a}}$ & $15.89 \pm 0.01_{\mathrm{b}^{* * *}}$ & $76.47 \pm 1.77_{\mathrm{a}}$ \\
\hline Dry matter (\%) & $19.33 \pm 4.1_{\mathrm{a}}$ & $84.11 \pm 0.01_{\mathrm{b}^{* *}}$ & $23.53 \pm 1.77_{\mathrm{a}}$ \\
\hline Moisture of flour (\%) & $7.67 \pm 0.46_{a}$ & $7.47 \pm 0.34_{a}$ & $8.13 \pm 0.12_{a}$ \\
\hline Dry mater of flour (\%) & $92.33 \pm 0.46_{\mathrm{a}}$ & $92.53 \pm 0.34_{\mathrm{a}}$ & $91.87 \pm 0.12_{\mathrm{a}}$ \\
\hline $\operatorname{Ash}(\% \mathrm{DM})$ & $10.90 \pm 0.42_{\mathrm{a}}$ & $27.45 \pm 0.31_{\mathrm{b}} * *$ & $11.30 \pm 3.54_{\mathrm{a}}$ \\
\hline Lipides (\%DM) & $22.06 \pm 5.40_{\mathrm{a}}$ & $26.79 \pm 2.3 \mathrm{a}$ & $19.08 \pm 4.6_{a}$ \\
\hline protein $(\% \mathrm{DM})$ & $64.42 \pm 1.51_{\mathrm{a}}$ & $38.75 \pm 7.19{ }_{b}{ }^{*}$ & $60.27 \pm 1.11_{\mathrm{a}}$ \\
\hline carbohydrates (\%DM) & $2.62 \pm 2.46_{\mathrm{a}}$ & $7.01 \pm 3.28_{\mathrm{a}}$ & $9.35 \pm 3.10_{\mathrm{a}}$ \\
\hline Energy (kcal/100gDM) & $466.70 \pm 64.48_{a}$ & $424.15 \pm 62.58_{\mathrm{a}}$ & $450.2 \pm 58.24_{\mathrm{a}}$ \\
\hline Calcium (mg/kg) & $7.92 \pm 0.22_{\mathrm{a}}$ & $5.68 \pm 0.84_{\mathrm{a}}$ & $5.23 \pm 0.61_{\mathrm{a}}$ \\
\hline Magnesium (mg/kg) & $12.98 \pm 6.7_{\mathrm{a}}^{* *}$ & $37.12 \pm 1.13_{\mathrm{b}}$ & $38.46 \pm 6.12_{b}$ \\
\hline Sodium (mg/kg) & $923.15 \pm 0.01_{\mathrm{a}}$ & $1384.72 \pm 0.00_{\mathrm{b}} *$ & $923.15 \pm 0.01_{\mathrm{a}}$ \\
\hline Potassium (mg/kg) & $7017.54 \pm 0.00_{\mathrm{a}}^{*}$ & $8187.13 \pm 1654.05_{\mathrm{b}}$ & $8771.93 \pm 827.02_{b}$ \\
\hline Phosphorus (mg/kg) & $406.25 \pm 44.20_{\mathrm{a}}$ & $343.75 \pm 44.20_{\mathrm{a}}$ & $375 \pm 0.01_{\mathrm{a}}$ \\
\hline Iron $(\mathbf{m g} / \mathbf{k g})$ & $1.70 \pm 0.01_{\mathrm{a}}$ & $1.20 \pm 1.17_{\mathrm{a}}$ & $2.70 \pm 0.01_{\mathrm{a}}$ \\
\hline Zinc (mg/kg) & Trace & Trace & Trace \\
\hline $\mathrm{Na} / \mathrm{K}$ & 0.13 & 0.17 & 0.11 \\
\hline
\end{tabular}

Values are shown as mean \pm standard deviation of triplicates. $\mathrm{N}=3$. Within the same line, values with different letters $(\mathrm{a}, \mathrm{b})$ are significantly different $(* \mathrm{P}<0.05 ; * * \mathrm{P}<0.01)$.

The effects of treatments on the proximate composition showed a drastic moisture decrement with the smoking. This dehydration concentrates the dry mater of fish, as well as its nutrient contents. This result is in agreement with those of Kumolu-Johnson et al. (2010) who reported the same observations. With respect to the dry matter, while value of ash content significantly $(\mathrm{P}<0.01)$ increases with the smoking process, the amount of proteins significantly decreases $(\mathrm{P}<0.01)$. The augmentation in ash content of smoked fish could be due to the loss of water during the process as explained in previous studies (Salan et al., 2006). Likewise, the observed statistically significant decrease of proteins amount in the present study during the smoking process, may affect the quality of food as stated in previous studies (Salan et al., 2006). The loss in available lysine may vary from 6-33\% at $25{ }^{\circ} \mathrm{C}$ to $53-56 \%$ at $40{ }^{\circ} \mathrm{C}$ during hot smoking (Dvorak \& Vognarova, 1965); $25 \%$ loss of available lysine on the surface and a $12 \%$ loss at the center of hot smoked fish (Clifford et al., 1980). Akande et al. (1998) observed that lysine reduction was directly proportional to the temperature and duration of smoking. However, the present study showed that boiling does not significantly $(\mathrm{P}>0.05)$ affect the proximate composition of $C$. nigrodigitatus.

The mineral contents of $C$. nigrodigitatus carried out in fresh, smoked and boiled are also shown in Table 1. In this fish, potassium content was higher $(7017.54-8771.93 \mathrm{mg} / \mathrm{kg}$ ), followed by sodium $(923.15-1384.72 \mathrm{mg} / \mathrm{kg}$ ), phosphorus $(343.75-406.25 \mathrm{mg} / \mathrm{kg})$, magnesium $(12.98-38.46 \mathrm{mg} / \mathrm{kg})$ and calcium $(5.23-7.92 \mathrm{mg} / \mathrm{kg})$. Iron was reported to be the least represented $(1.20-2.70 \mathrm{mg} / \mathrm{kg})$, while zinc was observed in traces. The ratio $\mathrm{Na} / \mathrm{K}$, increases (from 0.13 to 0.17 ) with smoking and decrease (from 0.13 to 0.11 ) with boiling. This report is very interesting in nutrition insofar as consumption of foods with high $\mathrm{Na} / \mathrm{K}$ ratio is often associated with high blood pressure (Liu, 1996). The $\mathrm{P}, \mathrm{Ca}$ and $\mathrm{Mg}$ are the essential components of the bones. Calcium and magnesium plays a significant role in photosynthesis, carbohydrate metabolism, nucleic acids and binding agents of cell walls (Russel, 1973). Calcium assists in teeth development (Brody, 1994). Magnesium is an essential mineral for enzyme activity; like calcium and chloride, magnesium also plays a role in regulating the acid-alkaline balance in the body (Fallon \& Enig, 2001). The order of predominance of these minerals from raw C. nigrodigitatus is different from the one obtained by Tenyang et al. (2016) on the same species collected in the Maga Lake. These last authors had found the order of predominance of $C$. nigrodigitatus minerals as $\mathrm{Ca}, \mathrm{P}, \mathrm{K}, \mathrm{Mg}, \mathrm{Na}, \mathrm{Zn}$ and $\mathrm{Fe}$ with respective values of $82938.9,35394.8,6117.5,1797.8,1072.3,122.8$ and $77.2 \mathrm{mg} / \mathrm{kg} \mathrm{dm}$. Thus, C. 
nigrodigitatus from Nkam River at Yabassi is less rich in minerals than the Maga Lake. The differences could be explained as previously by the variation in environmental factors (geographic areas, quality of water (temperature, salinity), availability of natural food and migration) and intrinsic (species, period of reproduction, age, sex and size at capture) (Ackman, 1990; Argen et al., 1991; Rao et al., 1995 \& Sargent et al., 2002 ).

Processing methods like smoking and boiling significantly $(\mathrm{P}<0.05)$ and positively affect the content in some minerals. For example, it is clearly noted in the table 1 that, it leads to an increment of potassium (16-25\%), magnesium (185-196\%) and sodium (50\%) content of fish. This corroborates the findings of Akinwumi (2014), who demonstrated that smoking of Clarias gariepinus increased its phosphorus, iron and potassium content. Similarly Effiong \& Fakunle (2012) observed high values of phosphorous and low iron contents in the three tropical smoked freshwater fishes studied. However, Eyo (2014) reported low phosphorous and iron contents, but high potassium and vitamin $\mathrm{C}$ contents in frozen fish. The current study is in contradiction with the report of Gokoglu et al., (2004) in regard to the effect of boiling on minerals contents. These authors observed a significant decrease in minerals $\mathrm{Na}, \mathrm{K}, \mathrm{Mg}, \mathrm{P}, \mathrm{Zn}$ and $\mathrm{Mn}$ after smoking. Flesh of freshwater fish is a particularly valuable source of minerals calcium and phosphorous as well as iron (FAO, 2014).

\subsection{Chemical Analyses for Lipids Quality}

The table 2 shows the effect of smoking and boiling on the oxidation parameters of $C$. nigrodigitatus oil. From this table, it is clearly observed that compared to extracted oil from raw fish, boiling and smoking have significantly affected the oil quality. The oil extracted from boiled fish has exhibited the highest peroxide and acid values, and the lowest iodine values in comparison to smoked and raw fishes. The index value of acid $(10.25 \%$ oleic acid which corresponds to $20.4 \mathrm{mg} \mathrm{KOH} / \mathrm{g}$ ) obtained in this work with the raw fish is at the limit ( $\leq 20 \mathrm{mg} \mathrm{KOH} / \mathrm{g}$ ) granted by the Codex Alimentarius for Virgin oils of fish rich in phospholipids. This value is greater than $7.33 \mathrm{mg} \mathrm{KOH} / \mathrm{g}$ obtained by Mouokeu et al. (2018) in C. nigrodigitatus dried and macerated into hexane. This difference could be justified by the extraction technique. The increase in acid value observed in fish oil after treatment might be attributed to the hydrolysis of lipid compounds (triglycerides, phospholipids, etc.) due to the effect of heating and water. At high temperature, water can catalyze the hydrolysis of lipids, leading to free fatty acids, which result in the increment of oil acidity and in the susceptibility of the released fatty acids easily oxydable especially if they are unsaturated. These results are in agreement with those of Labuza (1974) who observed an increment of free fatty acids in food during dehydration and storage processes.

Table 2. Oxidation parameters of oil extracted from raw, smoked and boiled C. nigrodigitatus

\begin{tabular}{|c|c|c|c|}
\hline Parameter & Raw & Smoked & Boiled \\
\hline Acid value ( $\%$ oleic acid) & $10.25 \pm 0.01_{\mathrm{a}}$ & $18.80 \pm 0.01_{\mathrm{b}}$ & $29.96 \pm 0.01$ c \\
\hline Iodine value ( $\mathrm{g}$ of $\mathrm{I}_{2} / 100 \mathrm{~g}$ ) & $56.37 \pm 0.22_{\mathrm{a}}$ & $52.66 \pm 0.01_{\mathrm{a}}$ & $51.60 \pm 4.59$ \\
\hline Peroxyde value (meq $\mathrm{O}_{2} / \mathrm{Kg}$ ) & $22.02 \pm 4.21_{\mathrm{a}}$ & $29.54 \pm 3.21_{\mathrm{ab}}$ & $35.00 \pm 0.01_{\mathrm{b}}$ \\
\hline
\end{tabular}

Values are shown as mean \pm standard deviation of triplicates. $\mathrm{N}=3$.

In the same line, values with different letters $(\mathrm{a}, \mathrm{b})$ are significantly different $(\mathrm{P}<0.05)$.

The iodine value of the raw samples was $56.37 \mathrm{~g} \mathrm{I}_{2} / 100 \mathrm{~g}$ of oils. This value was lower than 82.64 and $93 \mathrm{~g} \mathrm{I}_{2}$ /100g obtained respectively by Mouokeu et al. (2018) in the same fish and Tenyang (2015) in Arius maculatus. Smoking and boiling have not significantly affected $(\mathrm{P}>0.05)$ this parameter. These effects are not in the same line as those observed by Tenyang (2015). This author showed a significant decrease in the iodine value of Arius maculatus lipids after smoking and boiling. However, this result is in agreement with those of Onyeike and Oguike (2003) who found similar effects during heating of peanut oil. The observed variations could be explained by the inactivation of exogenous lipoxygenase responsible of oxidation (Eymard, 2003) and which depend on intrinsic factors of the samples, mainly, duration and temperature of the heat treatment (Franckel, 1998).

Table 2 also illustrates the changes in peroxide value of the tested fish oil before and after treatments. It is clearly observed that these treatments have significantly increased the peroxide value of oil. The highest value was noted in boiled fish oil samples, showing that boiling might accelerate the primary oxidation of fish oil as compared to smoking. This result is related to the result of acid value, because the same sample has exhibited the highest acid value. It is well known that hydrolysis of lipids leads to free fatty acids, which, if unsaturated, can rapidly undergo oxidation. The highest peroxide value obtained in boiled fish oil sample is contradictory to the observed findings of Tenyang (2015) during cooking by boiling and smoking of Arius maculatus fish. The observed increment in peroxide value is associated to the formation of primary oxidation products, mainly 
hydroperoxides. In fact, during heating, unsaturated fatty acids of oil can undergo auto oxidation, which can lead to the formation of these compounds. So these parameters strengthen on the primary oxidation status of oil. The peroxide value of the oils extracted from raw $C$. nigrodigitatus was $22.02 \mathrm{meq} \mathrm{O}_{2} / \mathrm{kg}$. This result was greater than 4.49 meq $\mathrm{O}_{2} / \mathrm{Kg}$ and smaller than $72 \mathrm{meq} \mathrm{O}_{2} / \mathrm{Kg}$ found respectively by Mouokeu et al. (2018) in the same fish and Tenyang (2015) in Arius maculatus oil.

\subsection{Changes in Fatty Acid Profile of Fish Oil during the Process}

The fatty acid profiles of raw, smoked and boiled samples of $C$. nigrodigitatus are presented in Table 3 .

Table 3. Fatty acid profiles of raw, smoked and boiled fish oils

\begin{tabular}{|c|c|c|c|}
\hline Fatty acids & Raw & Smoked & Boiled \\
\hline C10:0, Capric & $0.09 \pm 0.01_{\mathrm{a}}$ & $0.06 \pm 0.01_{b}$ & $0.10 \pm 0.01_{\mathrm{a}}$ \\
\hline C11:0, Undecanoate & $0.27 \pm 0.04_{a}$ & $0.24 \pm 0.03_{\mathrm{a}}$ & $0.85 \pm 0.11_{\mathrm{b}}$ \\
\hline C12:0, Lauric & $0.66 \pm 0.02_{\mathrm{a}}$ & $1.22 \pm 0.03_{\mathrm{b}}$ & $0.23 \pm 0.00_{c}$ \\
\hline C13:0, Tridecanoate & $0.16 \pm 0.03_{\mathrm{a}}$ & $0.33 \pm 0.04_{b}$ & $0.11 \pm 0.03_{\mathrm{a}}$ \\
\hline C14:0, Myristic & $2.91 \pm 0.06_{\mathrm{a}}$ & $3.60 \pm 0.07_{\mathrm{b}}$ & $2.05 \pm 0.06_{\mathrm{c}}$ \\
\hline C15:0, Pentadecanoic & $0.70 \pm 0.01_{\mathrm{a}}$ & $0.75 \pm 0.04_{\mathrm{a}}$ & $1.17 \pm 0.03_{\mathrm{b}}$ \\
\hline C16:0, Palmitic & $27.61 \pm 0.50_{\mathrm{a}}$ & $34.76 \pm 0.41_{b}$ & $22.91 \pm 0.10_{\mathrm{c}}$ \\
\hline C17:0, Heptadecanoic & $1.58 \pm 0.03_{\mathrm{a}}$ & $2.07 \pm 0.03_{\mathrm{b}}$ & $2.58 \pm 0.01_{\mathrm{c}}$ \\
\hline C18:0, Stearic & $11.29 \pm 0.21_{\mathrm{a}}$ & $12.29 \pm 0.14_{b}$ & $14.81 \pm 0.03_{\mathrm{c}}$ \\
\hline C20:0, Arachidic & $0.52 \pm 0.04_{\mathrm{a}}$ & $0.32 \pm 0.01_{\mathrm{b}}$ & $0.68 \pm 0.02_{\mathrm{c}}$ \\
\hline C21:0, Heneicosanoic & $0.17 \pm 0.01_{\mathrm{a}}$ & $0.16 \pm 0.09_{\mathrm{a}}$ & $0.32 \pm 0.13_{\mathrm{a}}$ \\
\hline C22:0, Behenic & $0.42 \pm 0.08_{\mathrm{a}}$ & $0.46 \pm 0.15_{\mathrm{a}}$ & $0.91 \pm 0.32_{\mathrm{a}}$ \\
\hline C23:0, Tricosanoic & $0.87 \pm 0.07_{\mathrm{a}}$ & $0.71 \pm 0.00_{\mathrm{b}}$ & $1.64 \pm 0.01_{\mathrm{c}}$ \\
\hline C24:0, Lignoceric & $0.18 \pm 0.02_{\mathrm{a}}$ & $0.27 \pm 0.01_{\mathrm{a}}$ & $0.43 \pm 0.05_{b}$ \\
\hline C14:1 Myristoleic & $0.09 \pm 0.03_{\mathrm{a}}$ & $0.56 \pm 0.49_{\mathrm{a}}$ & $0.50 \pm 0.29 \mathrm{a}$ \\
\hline C16:1, Palmitoleic & $5.88 \pm 0.10_{\mathrm{a}}$ & $5.68 \pm 0.06_{\mathrm{a}}$ & $3.00 \pm 0.04_{b}$ \\
\hline C17:1, cis-10 Heptadecanoic & $0.41 \pm 0.21_{\mathrm{a}}$ & $0.58 \pm 0.04_{\mathrm{a}}$ & $0.67 \pm 0.05_{\mathrm{a}}$ \\
\hline C18:1, Elaidic & & & $4.17 \pm 0.10$ \\
\hline C18:1, Oleic & $23.55 \pm 1.16_{\mathrm{a}}$ & $21.15 \pm 0.25_{\mathrm{a}}$ & $12.83 \pm 0.05_{b}$ \\
\hline C20:1, cis-11 Eicosenoic & $0.42 \pm 0.02_{\mathrm{a}}$ & $0.29 \pm 0.05_{\mathrm{ab}}$ & $0.20 \pm 0.01_{\mathrm{b}}$ \\
\hline C22:1, Erucic & $0.07 \pm 0.02_{\mathrm{a}}$ & $0.37 \pm 0.33_{\mathrm{a}}$ & \\
\hline C24:1, Nervonic & $0.09 \pm 0.04$ & & \\
\hline C18:2, Linolelaidic & $0.24 \pm 0.01_{\mathrm{a}}$ & $0.20 \pm 0.04_{\mathrm{a}}$ & \\
\hline C18:2, Linoleic (LA) $(\omega 6)$ & $6.75 \pm 0.17 \mathrm{a}$ & $3.62 \pm 0.10_{\mathrm{b}}$ & $2.83 \pm 0.10_{\mathrm{c}}$ \\
\hline C20:2, cis-11,14 Eicosadienoic ( $\omega 6)$ & $0.82 \pm 0.02_{\mathrm{a}}$ & $0.46 \pm 0.02_{\mathrm{b}}$ & $0.79 \pm 0.02_{\mathrm{a}}$ \\
\hline $\mathrm{C} 22: 2$, cis 13,16 Docosadienoic $(\omega 6)$ & $0.05 \pm 0.01_{\mathrm{a}}$ & $0.11 \pm 0.02_{\mathrm{a}}$ & \\
\hline C18:3, $\gamma$-linolenic (GLA) $(\omega 6)$ & $0.56 \pm 0.06_{a}$ & $0.48 \pm 0.12_{\mathrm{a}}$ & $0.45 \pm 0.11_{\mathrm{a}}$ \\
\hline C18:3, $\alpha$-linolenic $(\omega 3)$ & $1.32 \pm 0.04_{\mathrm{a}}$ & $2.37 \pm 0.05_{\mathrm{b}}$ & $1.47 \pm 0.04_{a}$ \\
\hline C20:3, cis-8,11,14 Eicosatrienoic (hGL) ( $\omega 6)$ & $1.43 \pm 0.05_{\mathrm{a}}$ & $1.07 \pm 0.02_{\mathrm{b}}$ & $0.87 \pm 0.07_{\mathrm{b}}$ \\
\hline C20:3, cis-11,14,17 Eicosatrienoic $(\omega 3)$ & $0.65 \pm 0.01_{\mathrm{a}}$ & $0.84 \pm 0.08_{\mathrm{b}}$ & $0.54 \pm 0.05 \mathrm{a}$ \\
\hline $\mathrm{C} 20: 4$, Arachidonic $(\omega 6)$ & $4.53 \pm 0.11_{\mathrm{a}}$ & $2.50 \pm 0.10_{\mathrm{b}}$ & $6.64 \pm 0.22_{\mathrm{c}}$ \\
\hline C20:5, Eicosapentaenoic (EPA) $(\omega 3)$ & $1.41 \pm 0.02_{\mathrm{a}}$ & $0.95 \pm 0.03_{\mathrm{b}}$ & $3.92 \pm 0.06_{\mathrm{c}}$ \\
\hline C22:6, Docosahexaenoic (DHA) $(\omega 3)$ & $4.33 \pm 0.04_{\mathrm{a}}$ & $1.56 \pm 0.00_{\mathrm{b}}$ & $12.31 \pm 0.17_{\mathrm{c}}$ \\
\hline$\Sigma$ Total Fatty acids & 100 & 100 & 100 \\
\hline Number of fatty acids & 32 & 31 & 29 \\
\hline$\Sigma$ Saturated Fatty acids (SFA) & $47.41 \pm 1.11_{a}$ & $57.23 \pm 1.06_{b}$ & $48.8 \pm 0.88_{a}$ \\
\hline$\Sigma$ Unsaturated Fatty acids (UFA) & $52.59 \pm 2.14_{a}$ & $42.77 \pm 1.80_{b}$ & $51.20 \pm 1.39$ a \\
\hline$\Sigma$ Monounsaturated fatty acids (MUFA) & $30.51 \pm 1.59$ a & $28.63 \pm 1.21_{a}$ & $21.37 \pm 0.55_{b}$ \\
\hline$\Sigma$ Polyunsaturated fatty acids (PUFA) & $22.08 \pm 0.55_{a}$ & $14.14 \pm 0.599_{b}$ & $29.83 \pm 0.8_{c}$ \\
\hline$\Sigma \mathbf{n - 3}$ & $7.7 \pm 0.12$ a & $5.72 \pm 0.17_{b}$ & $18.25 \pm 0.32_{c}$ \\
\hline$\Sigma n-6$ & $14.14 \pm 0.43_{\mathrm{a}}$ & $8.23 \pm 0.38_{b}$ & $11.59 \pm 0.52_{c}$ \\
\hline$n-3 / n-6$ & 0.54 & 0.69 & 1.57 \\
\hline PUFA/SFA & 0.47 & 0.25 & 0.61 \\
\hline
\end{tabular}

Values are shown as mean \pm standard deviation of triplicates.

In the same line, values with different letters $(a, b)$ are significantly different $(\mathrm{P}<0.05)$. 
Thirty two fatty acids were identified in raw samples of fish oil $C$. nigrodigitatus. This number is very high compared to 20 and 17 obtained by Mouokeu et al. (2018) on oil of the same fish species collected at Yabassi and extracted respectively by press after boiling and maceration into hexane. This number is also higher than 23 obtained by Tenyang et al. (2016) on C. nigrodigitatus from Lake Maga and 22 recorded by Tenyang et al. (2014) on A. maculatus from Wouri. These differences could be explained by some extrinsic factor and the extraction method used. The oil of raw fish of this study contains $47.41 \pm 1.11,30.51 \pm 1.59$, and $22.08 \pm 0.55 \%$ of saturated, monounsaturated and polyunsaturated fatty acids respectively. These proportions are also different from those of Tenyang et al. (2016) who recorded 43.52, 42.53 and 11.62 percent, respectively in the same fish from Lake Maga and Mouokeu et al. (2018) who also registered 50.09 - 51.72; 30.5 - 33.9 and 18.4 - $12.92 \%$ respectively on the same fish species.

The most abundant fatty acids were Palmitic acid (C16:0) and Oleic acid (C18:1) with $27.61 \pm 0.50 \%$ and $23.55 \pm 1.16 \%$ respectively. These results corroborate with those of previous authors on $C$. nigrodigitatus. Tenyang et al. (2016) found an abundance of 22.75 and 32.96\% while Mouokeu et al. (2018) found $27.5-34.0 \%$ and $23.9-26.3 \%$ of these two fatty acids respectively. Oleic acid is n-9 fatty acids which plays a moderate role in the body. The n- 6 fatty acids cannot be synthesized by humans and are therefore considered as essential fatty

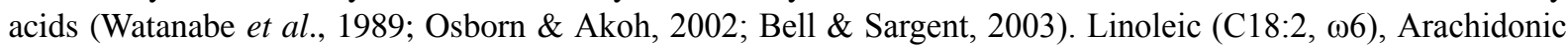
$(\mathrm{C} 20: 4, \omega 6)$ and Docosahexaenoic (DHA) $(\mathrm{C} 22: 6, \omega 3)$ acids were in general, the polyunsaturated fatty acids found in the largest percentages of $6.75 \pm 0.17 \%, 4.53 \pm 0.11 \%$ and $4.33 \pm 0.04 \%$ respectively. These findings are in line with previous studies conducted in catfish samples (Mouokeu et al., 2018; Tenyang et al., 2016; Tenyang et al., 2013; Weber et al., 2002; Sharai et al., 2002). DHA are the fatty acids predominant in n-3 series of $C$. nigrodigitatus. This fatty acid has been considered as important for brain, eyes development and good cardiovascular health (Conner, (1997). C. nigrodigitatus had low level of n-3 PUFA when compared to the sum of $n-6$. However, the value 0.54 recorded on the $n-3 / n-6$ ratio in this study is very high when compared to 0.3 and 0.2 obtained by Weber et al. (2002) and Sharai et al. (2002) respectively. These differences could be attributed to their diet. Several authors have concluded that FA profiles in fish reflect the diets of the animals (Zenebe et al., 1998a; 1998b, Ahmed et al., 2010; Tenyang et al., 2016; Osibona, 2011). Also, feeding of fish depend on the environmental conditions, including temperature, salinity, prey composition and types of metabolism (Sargent et al., 2002).

As shown in the table 3 , smoking has significantly increased $(\mathrm{P}<0.05)$ the amount of saturated fatty acids, meanwhile it has significantly reduced $(\mathrm{P}<0.05)$ the amounts of unsaturated ones $(\mathrm{n}-3$ and $\mathrm{n}-6$ polyunsaturated fatty acids). The increase in saturated fatty acids concerns Lauric, Tridecanoic, Myristic, Palmitic, Heptadecanoic and Stearic acids. Nervonic (C24:1) acid disappeared with this treatment. The decrease of polyunsaturated fatty acids concerns Linoleic, Cis-11, 14-Eicosadienoic, cis-8,11,14-Eicosatrienoic, Arachidonic, Eicosapentaenoic and Docosahexaenoic acids. The ratio PUFA/SFA regressed from 0.47 to 0.25 . Similar effects have been recorded in our precedent research in smoking of Oreochromis niloticus in the same zone (Djopnang et al., 2017). The decreased of this quality index could be related to the fat oxidation, which was confirmed by the previous results on the indices of acids and peroxides. From this effect, Julie (2002) concluded that Fat oxidation can decrease the level of essential fatty acids in the diet and can lower the overall food quality by introducing free radicals and other oxidized products. It is well known in the literature that a ratio of 0.2 is associated with hypercholesterolemia, while the oils with 0.8 ratios are recommended to prevent cardiovascular diseases (Rahman et al., 1995).

Boiling also affects the fatty acid profile. In general, the loss of four fatty acids with boiling is observed: Nervonic, Linolelaidic, Erucic and Docosadienoic ( $\omega 6)$. A new Elaidic acid was generated during cooking. The cooking processes did not significantly influence $(\mathrm{P}>0.05)$ the total saturated fatty acids, but, a significant $(\mathrm{P}<0.05)$ decrease in monounsaturated fatty acids is registered. In Contrast, a significant $(\mathrm{P}<0.05)$ increase in polyunsaturated fatty acids was registered with the increase of $n-3$ fatty acids. This process increased the nutritional status of n-3 PUFA like the $n-3 / n-6$ and PUFA/SFA ratios at 1.57 and 0.61 respectively, which are necessary for cardiovascular diseases prevention. These results are in agreement with our previous research in boiling of $O$. niloticus (Djopnang et al., 2017). The increase in PUFA concerns Docosahexaenoic (DHA, $\omega 3$ ), Eicosapentaenoic (EPA, $\omega 3$ ), and Arachidonic ( $\omega 6)$, while the decrease of MUFA and PUFA concerns

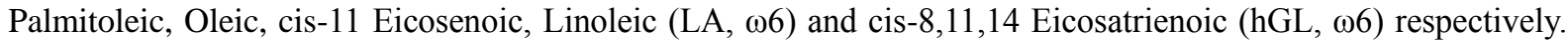
The increase in PUFA and different quality oils ratio of $C$. nigrodigitatus could be justified by extraction. Indeed, during extraction, fine grinding of the skin in raw samples was difficult unlike in boiled samples. Boiling has the role of weakening the cell membranes, and in turn facilitates the extraction of oils. The only source of higher fatty acids could reside in the subcutaneous fat deposit. Similar effects were observed by Kaitaranta (1980) on 
the Coregonus albula.

\section{Conclusion}

The present study consisted in an evaluation of the influence of smoking and boiling processes of a selected freshwater fish $C$. nigrodigitatus commercialized in Yabassi-Cameroon on the chemical composition and lipids qualities. This fish was found to be a good source of protein, minerals and fatty acids. It is equally rich in essential PUFAs, such as EPA and DHA, which are good for health. Processing by smoking and boiling methods applied to this fish influenced significantly its composition. Smoking concentrates ash value and decreases the amounts of water, protein, PUFA such as Docosahexaenoic (DHA), Eicosapentaenoic (EPA), Arachidonic, cis-8,11,14-Eicosatrienoic (hGL) and cis-11,14-Eicosadienoic and PUFA/SFA ratio. Thus, the drastic decline of this last parameter would indicate that oil of $C$. nigrodigitatus smoked could expose the consumer to cardiovascular diseases. Both processes led to an increase of potassium, sodium and magnesium. Lipid oxidation was revealed by the increase of free fatty acids and peroxide value. Moreover, boiling improved the values of the ratio Omega-3/Omega-6 and PUFA/AGS, which upgrade their nutritional status. Another advantage of this treatment resides in the fact that nutrients lost in the cooking water could be recovered by consuming its juice. Thus, boiling would be the best way for their nutritional valorization.

\section{Conflict of Interests}

The authors declare to do not have any conflict of interest.

\section{Acknowledgements}

The authors wish to thank Mrs. Gaby MBANJO, Dany NANTCHOUANG DJIBIE and NGASSA Gaelle for their valuable appreciation and discussion for the successful completion of this study.

\section{References}

Ackman, R. G. (1990). Seafood lipids and fatty acids. Food Rev. Int., 6, 617-646. https://doi.org/10.1080/87559129009540896

AFNOR (1981). Recueil des Normes Françaises. Corps Gras, Graines Oléagineuses, Produit Dérivés, $2^{\text {ème }}$ édition, AFNOR, Paris, P438.

Ahmed, E. O., Ali, M. E., Kalid, R. A., Taha, H. M., \& Mahammed, A. A. (2010). Investigating the quality changes of raw and hot smoked Oreochromis niloticus and Clarias lazera. Pak J Nut., 9, 481-484. https://doi.org/10.3923/pjn.2010.481.484.

Akande, G. R., Oladosu, O. H., \& Tobor, J. G. (1998). A Comparative technical and economic appraisal of fish smoking: Two traditional ovens \& a new Improved Magbon-Alade oven. FAO Fisheries Report, 574, 70-75.

Akinwumi, F. O. (2014). Effects of Smoking and Freezing on the Nutritive Value of African Mud Catfish, Clarias gariepinus (Burchell, 1822). Journal of Agricultural Science, 6(11), 143-149.

AOAC (2000). Official Methods of Analysis of AOAC International, 17th Edition. William Horwitz (Ed.). AOAC International, 2200.

AOAC. (1990). Official methods of analysis, 15 Edition, Washington DC, 222-245.

Argen, J. J., Al-Amad, H., \& Hanninen, O. (1991). Fatty acid content and composition of five fish species in the Persian Gulf. Comp. Biochem. Physiol. 100B, 339-341.

Azamand, K. M., \& Ali, Y. (2004). Biochemical Assessment on Selected Fresh Fish. Journal of Biological Sciences, 4(1), 9-10. https://doi.org/10.3923/jbs.2004.9.10.

Bell, J. G., \& Sargent, J. R. (2003). Arachidonic acid in aquaculture feeds: Current status and future opportunities, Aquaculture, 218, 491-499. https://doi.org/10.1016/S0044-8486(02)00370-8.

Bligh, E. G., \& Dyer, W. J. (1959). A Rapid Method of Total Lipid Extraction and Purification. Canadian Journal of Biochemistry \& Physiology, 37(8), 911-917. https://doi.org/10.1139/o59-099.

Brody, T. (1994). Nutritional Biochemistry. San Diego, CA: Academic Press. 2nd Edn, 761-794.

Christie, W. W. (1993). Preparation of esters derivatives of fatty acids for chromatographic analysis In Advances in Lipid Methodology, Two (Christie, W.W. ed.) Oily Press, Dundee, Scotland, 69-111.

Clifford, M. N, Tang, S. L., \& Eyo, A. A. (1980). The development of analytical methods for investigating chemical changes during fish smoking, Advances in Fish Science and Technology, Fishing News Books Limited, Farnham, 86-290. 
Conner W. E. (1997). The Beneficial Effects of Omega-3 Fatty Acids: Cardio Vascular Diseases and Neurodevelopment, Current Opinion in Lipidology, 8(1), 1-3. https://doi.org/10.1097/00041433-199702000-00001

Connor, W. E. (2000). Importance of n-3 fatty acids in health and disease. Am. J. Clin. Nutr. 71, 1715-1755. https://doi.org/10.1093/ajen/71.1.171S.

Djopnang, D. J., Njinkoue, J. M., Womeni, H. M., Gouado, I., Tomedi-Tabi, E. M., Tiwo, T. C., ... Tchoumbougnang, F. (2017). Valeur nutritionnelle et Influence de la période de capture, fumage et cuisson à ébullition sur le potentiel nutritionnel d'Oreochromis niloticus du fleuve Nkam (Yabassi-Cameroun). Cameroon Journal of Experimental Biology, 11(01), 34-46. Retrieved from http://www.ajol.info/browse-journals.php/

Dvorak, Z., \& Vognarova, I. (1965). Available lysine in meat and meat products. Journal of Science and Food Agriculture, 16(6), 305-310. https://doi.org/10.1002/jsfa.2740160604.

Effiong, B. N., \& Fakunle, J. O. (2012). Proximate and Mineral Content of Traditional Smoked Fish Species from Lake Kainji, Nigeria. Bulletin of Environment, Pharmacology and Life Sciences, 1(4), 43-45.

Eymard, S. (2003). Mise en Evidence et Suivi de l'Oxydation des Lipides au Cours de la Conservation et de la Transformation du Chinchard (Trachurus trachurus), Choix des Procédés, Thèse de Doctorat, Université de Nantes, 143P.

Eyo, A. A. (2014). Effects of Smoking and Freezing on the Nutritive Value of African Mud Catfish, Clarias gariepinus (Burchell, 1822). Journal of Agricultural Science, 6(11), 143-149.

Fallon, S., \& Enig, M. G. (2001). Nourishing Traditions. The Cook book that Challenges Policitally Correct Nutrition and the Diet Dictocrats. Revised 2nd Edn., 40-45.

FAO \& WHO (Food and Agriculture Organization \& World Health Organisation) (2007). Protein and amino acid requirements in human nutrition. Report of a joint WHO/FAO/UNU Expert Consultation. WHO Technical Report Series 935. Geneva, Switzerland, Cholé-Doc No 111.

FAO, (2014). Sustainable fisheries and aquaculture for food security and nutrition, Food and Agriculture Organization of the United Nations. 119. Retrieved from http://www.fao.org/documents/card/en/c/63d4de9f-50df-49b1-b6d2-b7d0368744ea.

Franckel, E. N. (1998). Lipid oxidation. The Oily press 10, Dundee, Scotland.

Gokoglu, N., Yerlikaya, P., \& Cengiz, E. (2004). Effects of cooking methods on the proximate composition and mineral contents of rainbow trout (Oncorhynchus mykiss). Food Chemistry, 84, 19-22. https://doi.org/10.1016/S0308-8146(03)00161-4.

Hopkins, C., Teugels, G., \& Stiassny, M. L. (2007). Poissons d'eaux douces et eaux saumâtres de basse Guinée, Ouest de l'Afrique Centrale. Vol1. Paris. France: Institut de Recherche pour le Développement. 805.

Julie, M. J. (2002). Chapter 13: Food safety. In Zdzislaw E. Sikorski, Second Edition Chemical and Functional Properties of Food Components, ISBN 1-58716-149, pp 291-306.

Kaitaranta, J. K. (1980). Lipids and fatty acids of whitefish (Coregonus albula) flesh and roe, J. Sci. Food Agric., 31, 1303-1308. https://doi.org/10.1002/jsfa.2740311213.

Krauss, R. M., Eckel, H. R., Howard, B., Appel, L. J., Daniels, S. R., Deckelbaum, R. J., ... Bazzarre, T. L. (2000). AHA Dietary Guidelines, Revision 2000: A Statement for Healthcare Professionals from the Nutrition Committee of American Heart Association. Circulation, 102, 2284-2299. https://doi.org/10.1161/01.CIR.102.18.2284.

Kris-Etherton, P. M., Harris, W. S., \& Appel, L. J. (2003). Fish consumption, fish oil, Omega-3 fatty acids and cardiovascular disease. Arteriosclerosis Thrombosis Vascular Biology, 23, 20-31. https://doi.org/10.1161/01.ATV.0000038493.65177.94

Kumolu-Johnson, C. A. A., \& Ndimele, P. E. (2010). The effects of smoking on the nutritional qualities and shelf-life of Clarias gariepinus (BURCHELL 1822). African Journal of Biotechnology, 9(1), 073-076.

Labuza, T. P. (1974). Effect of Dehydration and Storage on Nutrient Retention in Food. Food Technology, 27, 20-26.

Liu, Y.C. (1996). Food Chemistry. Chinese Light Industry Press, Beijing, 83.

Mouokeu, R. S., Womeni, H. M., Njike, N. F. H., Tonfack, D. F., Djopnang, D. J., Tchoumbougnang F., \& Kuiate, 
J. R. (2018). Chemical composition and antibacterial activity of oils from Chrysicthys nigrodigitatus and Hepsetus odoe, two fresh water fishes from Yabassi, Cameroon. Lipids in Health and Disease, 17, 45. https://doi.org/10.1186/s12944-018-0690-z.

Mozaffarian, D., Ascherio, A., Hu, F. B., Stampfer, M. J., Willet, W. C., Siscovick, D. S., \& Rimm, E. R. (2005). Interplay between different polyunsaturated fatty acids and risk of coronary heart disease in men. Circulation, 11, 157-164. https://doi.org/10.1161/01.CIR.0000152099.87287.83

Olele, N. F. (2012). Nutrient composition of Gnathonemus tamandua, Chrysichtys nigrodigitatus and Anchenoglanis bisculatus caught from river Niger. Nig. J. Environ., 8(2), 21-27.

Onyeike, E. N., Ayoologu, E. O., \& Ibegbulam, C. O. (2000). Evaluation of the nutritional value of some crude oil in polluted freshwater fishes, Global Journal of Pure and Applied Sciences, 6, 227-233. https://doi.org/10.4314/gjpas.v6i2.16112.

Onyeike, N. E., \& Oguike, U. J. (2003). Influence of Heat Processing Methods on the Nutrient Composition and Lipid Characterization of Groundnut (Arachis hypogeaa) Seed Pastes, Biokemistri, 15(1), 34-43.

Onyeike, N. E., \& Oguike, U. J. (2003). Influence of Heat Processing Methods on the Nutrient Composition and Lipid Characterization of Groundnut (Arachis hypogeaa) Seed Pastes. Biokemistri, 15(1), 34-43.

Osborn, H. T., \& Akoh, C. C. (2002). Structured lipids-novel fats with medical, nutraceutical and food applications, Comp. Rev. Food Sci., 3, 93-103.

Osibona, A. O. (2011). Comparative study of proximate composition, amino and fatty acids of some economically important fish species in Lagos, Nigeria. Afr. J. Food Sci., 5, 581-8.

Pauwels, J. M., Van Ranst, E., Verloo, M., \& Mvondo, Z. A. (1992). Manuel de laboratoire de pédologie, Publication Agricole, AGCD, 28, 263.

Rahman, S. A., Huah, T. S., Nassan, O., \& Daud, N. M. (1995). Fatty acid composition of some Malaysian fresh water fish. J. Food Chem., 54, 45-49. https://doi.org/10.1016/0308-8146(95)92660-C.

Rao, V. S., Adhikari, H. R., \& Nair, P. M. (1995). Fatty acid composition of some Indian fish varieties. ASEAN Food J., 10(2), 62-65.

Russel, E.W. (1973). Soil conditions and plant growth. Supergene Zone, M. Nedra, 19 (in Russian).

Salán, O. E., Juliana, A. G., \& Marilia, O. (2006). Use of smoking to add value to salmoned trout, Braz. Arch. Biol. Technol., 49(1), 57-62. https://doi.org/10.1590/S1516-89132006000100007.

Sargent, J. R., Tocher, D. R., \& Gordon, B. J. (2002). The lipids, In Halver JE, Hardy RW, eds. Fish nutrition. Academic Press, Elsevier Science, New York, 181-257.

Sharai, N., Suzuki, H., Tokairin, S., Ehara, H., \& Wada, S. (2002). Dietary and Seasonal Effects on the Dorsal Meat Lipid Composition of Japanese (Silurus asotus) and Thai Cat- fish (Clarias macrocephalus and Hybrid Clarias macrocephalus and Clarias gariepinus). Comparative Biochemistry and Physiology Part A, 132(76), 609-619. https://doi.org/10.1016/S1095-6433(02)00081-8.

Suzuki, H. S., Park, J., Tamura, M., \& Ando, S. (1998). Effect of the long-term feeding of dietary lipids on the learning ability, fatty acid composition of brain stem phospholipids and synaptic membrane fluidity in adult mice: a comparison of sardine oil diet with palm oil diet. Mechanisms of Ageing and Development, 101, 119-128. https://doi.org/10.1016/S0047-6374(97)00169-3.

Tenyang, N., Ponka, R., Tiencheu, B., Tonfack, D. F., \& Womeni, H. M. (2016). Proximate Composition, Fatty Acid and Mineral Contents of Four Freshwater Fish from Maga Lake (Far North Region of Cameroon). American Journal of Food Science and Technology, 4(3), 64-69. https://doi.org/10.12691/ajfst-4-3-2.

Tenyang, N. (2015). Poissons gras consommés au Cameroun: caractérisation chimique, influence des traitements culinaires et de conservations sur la qualité des lipides et les propriétés fonctionnelles des protéines des tourteaux. (Thèse de Doctorat/Ph.D en Biochimie non publiée) Université de Dschang, Dschang, Cameroun, 186P.

Tenyang, N., Womeni, H. M., Linder, M., Tiencheu, B., Villeneuve, P., \& Tchouanguep, M. F. (2014). The chemical composition, fatty acid, amino acid proiles and mineral content of six ish species commercialized on the Wouri river coast in Cameroon. LA RIVISTA ITALIANA DELLE SOSTANZE GRASSE GRASSE VOL. XCI - APRILE/GIUGNO: 129-138.

Tenyang, N., Womeni, H. M., Tiencheu, B., Hrodrik, N., Takugan, F., Tchouanguep, M. F., Villeneuve, P., \& 
Linder, M. (2013). Lipid Oxidation of Catfish (Arius maculatus) after Cooking and Smoking by Different Methods Applied in Cameroon. Food and Nutrition Sciences, 4, 176-187. https://doi.org/10.4236/fns.2013.49A1025

Vivien (1991). Faune du Cameroun : guide des mammifères et poissons. GICAM et Ministère de la coopération et du développement. Yaoundé, 271.

Watanabe, T., Arakawa, T., Takeuchi, T., \& Satoh, S. (1989). Comparison between eico sapentaenoic and docosahexaenoic acids in terms of essential fatty acid efficiency in juvenile striped jack Pseudocaranx dentex. Nippon Suisan Gakkasihi, 55, 1989-1995. https://doi.org/10.2331/suisan.55.1989.

Weber, J., Bochi, V. C., Ribeiro, C. P., Victorio, A. M., \& Emanuelli, T. (2002). Effect of Different Cooking Methods on Oxidation, Proximate and Fatty Acid Composition of Silver Catfish (Rhamdia quelen) Fillets. Food Chemistry, 106(1), 140-146. https://doi.org/10.1016/j.foodchem.2007.05.052.

Yeannes, M. J., \& Almandos, M. E. (2003). Estimation of fish proximate composition starting from water content. Journal of Food Composition and Analysis, 16, 81-92. https://doi.org/10.1016/S0889-1575(02)00168-0.

Zenebe, T., Ahlgren, G., \& Boberg, M. (1998a). Fatty acid content of some freshwater fish of commercial importance from tropical lakes in the Ethiopian Rift Valley. J Fish Biol., 53, 987-1005. https://doi.org/10.1111/j.1095-8649.1998.tb00458.x.

Zenebe, T., Ahlgren, G., Gustafsson, I. B., \& Boberg, M. (1998b). Fatty acid and lipid content of Oreochromis niloticus L. in Ethiopian lakes dietary effects of phytoplankton. Ecol. Freshw. Fish, 7, 146-58. https://doi.org/10.1111/j.1600-0633.1998.tb00181.x.

\section{Copyrights}

Copyright for this article is retained by the author(s), with first publication rights granted to the journal.

This is an open-access article distributed under the terms and conditions of the Creative Commons Attribution license (http://creativecommons.org/licenses/by/4.0/). 